Article

\title{
Essential Oil Composition and Bioactivities of Waldheimia glabra (Asteraceae) from Qinghai-Tibet Plateau
}

\author{
Ji De ${ }^{1}$, Yan Lu ${ }^{2, *}$, Lijun Ling ${ }^{2}$, Nan Peng ${ }^{3}$ and Yang Zhong ${ }^{3, *}$ \\ 1 College of Science, Tibet University, Lhasa 8500, Tibet, China; 12110700018@fudan.edu.cn \\ 2 School of Pharmacy, Fudan University, Shanghai 201203, China; 13111030032@fudan.edu.cn \\ 3 School of Life Science, Fudan University, Shanghai 200438, China; nanpeng@fudan.edu.cn \\ * Correspondence: luyan@fudan.edu.cn (Y.L.); yangzhong@fudan.edu.cn (Y.Z.); \\ Tel.: +86-21-5198-0157 (Y.L.); +86-21-6564-3306 (Y.Z.)
}

Academic Editors: Olga Tzakou and Derek J. McPhee

Received: 26 December 2016; Accepted: 11 March 2017; Published: 13 March 2017

\begin{abstract}
Waldheimia glabra is traditionally used as incense and as an anti-influenza drug by Tibetans in China. Here, we collected W. glabra from the Gangs Rinpoche mountain at an altitude of $5200 \mathrm{~m}$, and analyzed its essential oil by gas chromatography-mass spectrometry (GC-MS) combined with the retention indices (RI). Twenty-seven compounds, representing $72.4 \%$ of the total essential oil, were identified, including $\alpha$-bisabolol $(20.2 \%)$, valeranone (11.8\%), chamazulene $(9.9 \%)$, spathulenol $(8.2 \%), \beta$-caryophyllene (6.1\%), and caryophyllene oxide (5.2\%). Bioactivity evaluation of the essential oil revealed that it exhibited potent anti-influenza effect on viruses $\mathrm{H}_{3} \mathrm{~N}_{2}$ and anti-inflammatory effect by inhibiting the lipopolysaccharide (LPS)-induced nitric oxide (NO) production in RAW 264.7 macrophages, but no anti-complementary activity.
\end{abstract}

Keywords: Waldheimia glabra; Tibetan medicine; essential oil; anti-influenza; anti-inflammatory

\section{Introduction}

Waldheimia glabra (Decne.) Regel (Tibetan name: 'ghaan-poe') is mainly distributed in India, Nepal, Pakistan, Afghanistan, and China. In China, W. glabra is mainly distributed in the areas of Tingri, Nyalam, Zhada, and Rituo at altitudes above 4000-5400 $\mathrm{m}$ in Tibet, along the Transhimalayan Mountain [1]. Himalaya is a global central region of species-rich diversity [2]. Many plants in this cold and high altitude region have been traditionally used as Tibetan medicine for their amazing efficacy in healthcare. Although it has not yet been recorded in Tibetan medicine, W. glabra was traditionally believed to prevent colds and fever by local people in Tibet by making incense or soup. As reported by Giorgi et al. [3] and Manzo et al. [4], W. glabra was used in Tibetan medicine for the treatment of influenza, cold, wounds, fever, and skin diseases. However, the bioactive constituents and pharmacological actions of this plant were rarely reported.

Plant essential oils always exhibit a number of biological properties, such as antibacterial, antiviral, anti-fungal, and anti-inflammatory activities, etc. [5]. The essential oil of $W$. glabra is supposed to have interesting bioactivities related to the medical use of $W$. glabra. As reported [4], 75-78 volatile compounds and 27 essential oil compounds in W. glabra from Khumbu Valley, Nepal have been determined using HS-SPME GC-MS [3] and GC-MS, respectively. However, depending on the method of extraction employed, their major constituents were quite different. The HS-SPME volatiles mainly contained $\alpha$-pinene $(38.87 \%-48.35 \%), \beta$-phellandrene $(25.86 \%)$, and seychellene $(7.09 \%-11.54 \%)$ [3], while the essential oil mainly contained spathulenol (24.83\%), $\alpha$-bisabolol (7.80\%), 9-tetradecenol $(7.65 \%)$, thujopsene $(6.60 \%), \alpha$-thujone $(5.69 \%)$, and yomogi alcohol $(5.08 \%)$ using IBM Statistical Package for Social Sciences v. 20 software (SPSS, IBM, Segrate, Milan, Italy) for statistical analyses [4]. 
Herein, we collected W. glabra from the Gangs Rinpoche Mountain at an altitude of $5200 \mathrm{~m}$ in Tibet (Trans-himalaya Mountain Range in Tibet), China and analyzed its essential oil constituents by GC-MS. In addition, for further exploitation of this plant, the possible bioactivities of the essential oil of W. glabra were examined, including anti-influenza, anti-inflammatory, and anti-complementary activities.

\section{Results}

\subsection{Chemical Composition of Essential Oil}

Hydrodistillation of W. glabra yield $1.5 \%(v / w)$ of the yellow essential oil using the Chinese Pharmacopoeia appendix method [6]. The identification by mass fragmentation and retention indices (RI) revealed the presence of 27 components representing $72.4 \%$ of the total oil. The components and their relative percentage are presented in Table 1 . The results showed that the major constituents were $\alpha$-bisabolol (20.2\%), valeranone (11.8\%), chamazulene $(9.9 \%)$, spathulenol $(8.2 \%), \beta$-caryophyllene $(6.1 \%)$, and caryophyllene oxide $(5.2 \%)$, with oxygenated sesquiterpenes $(59.1 \%)$ being the main class of compounds, followed by sesquiterpene hydrocarbons (8.7\%) and oxygenated monoterpenes (3.9\%), using relative quantification by GC-MS.

Table 1. Chemical composition of the essential oil of W. glabra from Tibet.

\begin{tabular}{|c|c|c|c|}
\hline No. & Compounds & $\%$ Area & RI $^{1}$ \\
\hline 1 & $\alpha$-Pinene & 0.3 & 944 \\
\hline 2 & Yomogi alcohol & 1.4 & 996 \\
\hline 3 & Artemisia ketone & 0.2 & 1066 \\
\hline 4 & Artemisia alcohol & 0.5 & 1086 \\
\hline 5 & Tanacetone & 0.2 & 1122 \\
\hline 6 & Lavandulol & 0.4 & 1173 \\
\hline 7 & Terpinen-4-ol & 0.2 & 1197 \\
\hline 8 & $\alpha$-Terpineol & 0.2 & 1212 \\
\hline 9 & $\beta$-Citronellol & 0.8 & 1234 \\
\hline 10 & Bornyl acetate & 0.2 & 1299 \\
\hline 11 & $\beta$-Caryophyllene & 6.1 & 1445 \\
\hline 12 & $\beta$-Farnesene & 1.0 & 1459 \\
\hline 13 & $\alpha$-Himachalene & 0.4 & 1493 \\
\hline 14 & $\alpha$-Curcumene & 0.5 & 1496 \\
\hline 15 & Citronellyl butanoate & 1.0 & 1531 \\
\hline 16 & $\delta$-Cadinene & 0.8 & 1537 \\
\hline 17 & Geranyl butyrate & 0.2 & 1564 \\
\hline 18 & Citronellyl iso-valerate & 1.7 & 1579 \\
\hline 19 & Patchoulanol & 0.4 & 1588 \\
\hline 20 & Spathulenol & 8.2 & 1608 \\
\hline 21 & Caryophyllene oxide & 5.2 & 1617 \\
\hline 22 & Isospathulenol & 0.4 & 1661 \\
\hline 23 & $\alpha$-Bisabolol & 20.2 & 1706 \\
\hline 24 & Valeranone & 11.8 & 1713 \\
\hline 25 & Hexahydrofarnesyl acetone & 0.2 & 1848 \\
\hline 26 & Tonghaosu & 0.2 & 1980 \\
\hline \multirow[t]{10}{*}{27} & Chamazulene & 9.9 & 2002 \\
\hline & Monoterpene hydrocarbons & 0.3 & \\
\hline & Oxygenated monoterpenes & 3.9 & \\
\hline & Sesquiterpene hydrocarbons & 8.7 & \\
\hline & Oxygenated sesquiterpenes & 59.1 & \\
\hline & Ketones & 0.2 & \\
\hline & Ester & 0.2 & \\
\hline & Total identified & 72.4 & \\
\hline & Others & 24.1 & \\
\hline & Total detected & 96.5 & \\
\hline
\end{tabular}

\footnotetext{
${ }^{1}$ Retention Indices, relative to C8-C30 n-alkanes on the HP-5MS column.
} 


\subsection{Anti-Influenza Activity of Essential Oil from W. glabra}

In order to confirm the possible activity of W. glabra for anti-influenza in Tibetan folk medicine, the essential oil was evaluated for its cytotoxicity and inhibition against the influenza virus $\mathrm{H}_{3} \mathrm{~N}_{2}$ in vitro by complete cytopathic effect (CPE) inhibition rate assay [7], with ribavirin as the positive control. As shown in Table 2, Ribavirin had good virucidal activity with $\mathrm{IC}_{50}$ value of $37.2 \mu \mathrm{g} \cdot \mathrm{mL}^{-1}$ and no cytotoxicity at $250 \mu \mathrm{g} \cdot \mathrm{mL}^{-1}$. The $\mathrm{IC}_{50}$ value of the essential oil was $88.8 \mu \mathrm{g} \cdot \mathrm{mL}^{-1}$, suggesting the moderate anti-influenza effect of $W$. glabra essential oil. However, the essential oil showed cytotoxicity against the MDCK cells at $200 \mu \mathrm{g} \cdot \mathrm{mL}^{-1}$, with the $\mathrm{TC}_{50}$ value of $252 \mu \mathrm{g} \cdot \mathrm{mL}^{-1}$.

Table 2. In vitro antiviral activity against $\mathrm{H}_{3} \mathrm{~N}_{2}$ of $W$. glabra essential oil.

\begin{tabular}{|c|c|c|c|c|c|}
\hline Samples & $\begin{array}{c}\text { Concentrations } \\
\left(\mu \mathrm{g} \cdot \mathrm{mL}^{-1}\right)\end{array}$ & $\begin{array}{c}\text { Cytotoxicity } \\
(\%)\end{array}$ & $\begin{array}{c}\mathrm{TC}_{50}{ }^{\mathrm{a}} \\
\left(\mu \mathrm{g} \cdot \mathrm{mL}^{-1}\right)\end{array}$ & $\begin{array}{c}\text { Inhibition Rate } \\
\text { for CPE (\%) }\end{array}$ & $\begin{array}{c}\mathrm{IC}_{50}^{\mathrm{b}} \\
\left(\mu \mathrm{g} \cdot \mathrm{mL}^{-1}\right)\end{array}$ \\
\hline \multirow{5}{*}{ Essential oil } & 200 & 50 & 252.0 & / & 88.8 \\
\hline & 100 & 0 & & 37.5 & \\
\hline & 50 & 0 & & 25 & \\
\hline & 25 & 0 & & 0 & \\
\hline & 12.5 & 0 & & 0 & \\
\hline \multirow{2}{*}{ Ribavirin } & 250 & 0 & & 75 & 37.2 \\
\hline & 125 & 0 & & 75 & \\
\hline
\end{tabular}

${ }^{\text {a }} \mathrm{TC}_{50}$ is $50 \%$ cytotoxic concentration. ${ }^{\mathrm{b}} \mathrm{IC}_{50}$ is the concentration of the sample inducing $50 \%$ inhibition. " /" not determined because of the cytotoxicity at $200 \mu \mathrm{g} \cdot \mathrm{mL}^{-1}$.

\subsection{Anti-Inflammatory Activity of Essential Oil from W. glabra}

Since the inhibitors of NO production in macrophages via lipopolysaccharide (LPS) stimulation are considered as anti-inflammatory agents, we determined the inhibitory effect of $W$. glabra essential oil on the NO production of RAW 264.7 macrophages using Griess assay [8]. As shown in Figure 1, the essential oil samples at $20 \mu \mathrm{g} \cdot \mathrm{mL}^{-1}$ and $100 \mu \mathrm{g} \cdot \mathrm{mL}^{-1}$ exhibited significant anti-inflammatory activities on the LPS stimulated cells in a dose-dependent manner. Especially, the essential oil at $100 \mu \mathrm{g} \cdot \mathrm{mL}^{-1}$ showed a stronger inhibitory effect than the positive control.

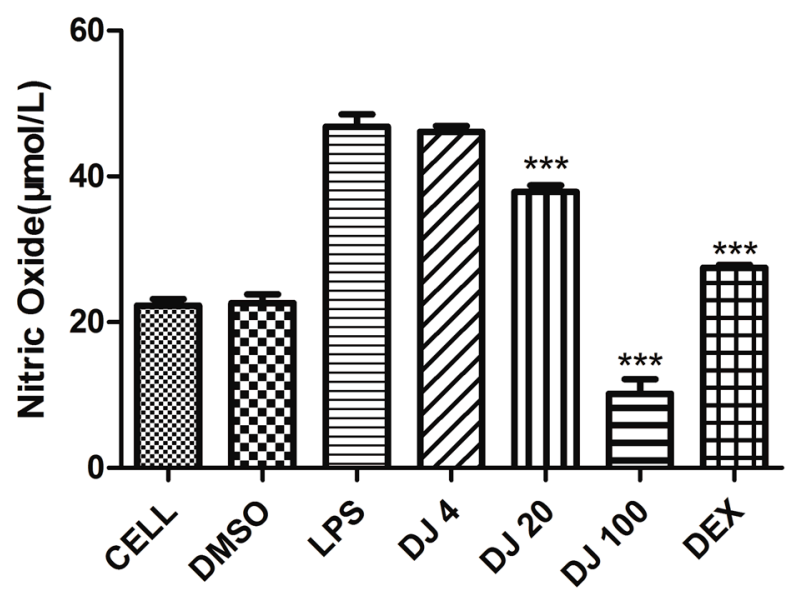

Figure 1. NO inhibitory effects of W. glabra essential oil on lipopolysaccharide (LPS)-activated RAW 264.7 cells. CELL: blank control; DMSO: blank control with DMSO; LPS: LPS control; DJ4, DJ20 and DJ100: the essential oil at 4, 20 and $100 \mu \mathrm{g} \cdot \mathrm{mL}^{-1}$ respectively; DEX: positive control of Dexamethasone; ***: $p<0.001$ vs. LPS group $(n=4)$. 


\subsection{Anti-Complementary Activity of Essential Oil}

The W. glabra essential oil was evaluated for in vitro anti-complementary activity on classical pathway with the method of Yin et al. [9]. The result indicated that the essential oil had no anti-complementary activity at the value of $50 \%$ inhibitory concentration $\left(\mathrm{CH}_{50}\right)>2 \mathrm{mg} \cdot \mathrm{mL}^{-1}$.

\section{Discussion}

Tibetan medicine has been a hot topic in recent years because of its magical medicine theory, multi-herb compatibility complex system, and various medical effects. Therefore, the analysis of the chemical composition of this Tibetan medicinal herb and its bioactivities are of great importance for Tibetan medicine development. Herein, we firstly reported the in vitro anti-influenza and anti-inflammatory effects of the essential oil of W. glabra, which were concordant with the plant's folk medicinal use on cold and fever in people. However, the essential oil did not show the expected anti-complementary activity. It is interesting that the non-volatile extract of $W$. glabra was found to show potent anti-complementary activity with $\mathrm{CH}_{50}$ less than $0.1 \mathrm{mg} \cdot \mathrm{mL}^{-1}$ in the subsequent study, but no anti-influenza activity. It suggested that $W$. glabra is a very useful resource of Tibetan medicine to treat inflammatory diseases induced especially by the influenza virus, with the essential oil directly killing the influenza virus and the anti-complementary extract inhibiting the excessive activation of the immune system [9]. The different roles and synergistic effect of these two extracts on influenza virus induced inflammation and fever in vivo are worth investigating and discussing in the near future, as well as the possible mechanism. The major anti-influenza compounds of the essential oil and the anti-complementary constituents of the non-volatile extract will also be investigated.

The result of GC-MS analysis indicated that $\alpha$-bisabolol, valeranone, spathulenol, caryophyllene, and caryophyllene oxide were the major compounds of W. glabra. It is worth noting that some major compounds had been isolated from other plants and reported to have various bioactivities. $\alpha$-Bisabolol isolated from Pogostemon speciosus [10], Eremanthus erythropappus [11], and Matricaria chamomilla [12] was considered to have anti-inflammatory, antibiotic, anticancer, antimicrobial, and antioxidant activities. Valeranone in Valeriana officinalis [13] and Valeriana wallichii [14] were reported for its anti-inflammatory effect. Spathulenol in Lantana camara characterized antifungal activity [15]. Caryophyllene and caryophyllene oxide in Teucrium pseudochamaepitys presented antioxidant, cytotoxic, and antiviral activities [16]. Therefore, we can infer that the properties of anti-influenza and anti-inflammation of essential oil of W. glabra may due to these major chemical compounds.

Many components of W. glabra essential oil collected in Tibet were similar to those reported from the Nepal sample [4], including $\alpha$-pinene, yomogi alcohol, $\beta$-citronellol, artemisia alcohol, terpinen-4-ol, $\alpha$-terpineol, caryophyllene, $\beta$-farnesene, $\beta$-chamigrene, $(-)$-aristolene, $\alpha$-curcumene, H-2,4a-ethanonaphthalene, 1,3,4,5,6,7-hexahydro-2,5,5-trimethyl, aromadendrene, $\alpha$-bisabolol, (+)-spathulenol, caryophyllene oxide, cedrol, hanphyllin, and spathulenol. However, there was a great difference in their major compounds and percent contents. The essential oil of W. glabra from Tibet, China mainly contained $\alpha$-bisabolol (20.2\%), valeranone $(11.8 \%)$, chamazulene $(9.9 \%)$, spathulenol (8.2\%), $\beta$-caryophyllene (6.1\%), and caryophyllene oxide $(5.2 \%)$, whereas spathulenol (24.8\%), $\alpha$-bisabolol (7.8\%), 9-tetradecenol (7.7\%), thujopsene (6.6\%), $\alpha$-thujone (5.7\%), and yomogi alcohol (5.1\%) were reported as representative compounds in the essential oil of $W$. glabra from Nepal.

The difference of aromatic compounds in the same species depends on different factors, such as extraction and analytical method, harvesting time, collecting parts, isolation procedure of aroma compounds, and climate change, etc. [17]. In addition, the Himalayas are a global central region of species-rich diversity, where slight changes on altitude and climate may influence the aromatic compounds [18]. On the other hand, the Himalaya Mountain region is considered as an important factor contributing to high population differentiation and a directional barrier to gene flow [19]. Therefore, the variation of chemical diversity in the same species in the Himalayan region is possible. The essential oils analyzed in this study and in the literature [4] were extracted by the method of distillation using the same aerial parts of W. glabra. However, the plant samples were collected at the 
end of August from Tibet and at the end of October from Nepal. The harvesting time and distribution might be the major factors for the difference of the volatile constituents in the two W. glabra samples.

\section{Materials and Methods}

\subsection{Plant Material and Extraction of Essential Oil}

The whole plant (flower, stems and leaves) of W. glabra was collected from the Gangs Rinpoche Mountain at an altitude of 5200 m, Qinghai-Tibetan Plateau, China at the end of August 2013, and identified by Prof. Peng-Cheng Lin (Qinghai Nationalities University, Xining, China). A voucher specimen (DJGb-2013730) was deposited in the Herbarium of Biodiversity Science and Geobiology of Tibet University.

One hundred grams of the dried, crushed, whole plant of W. glabra were subjected to $1000 \mathrm{~mL}$ of distilled water, and then distilled according to the Chinese Pharmacopoeia appendix method [8], slightly boiled for $3 \mathrm{~h}$, leading to $1.5 \mathrm{~mL}$ of the essential oil being collected.

\subsection{Identification of the Components of Essential Oil}

The GC-MS analysis of essential oil was carried out on a Thermofocus DSQII (Thermo, Wilmington, DE, USA), equipped with an HP-5MS column $(30 \mathrm{~m} \times 0.25 \mathrm{~mm}$, film thickness $0.25 \mu \mathrm{m})$. The oven temperature was programmed from $60^{\circ} \mathrm{C}(1 \mathrm{~min}$ isothermal $)$ to $300^{\circ} \mathrm{C}$ at a rate of $15^{\circ} \mathrm{C} / \mathrm{min}$, and then kept for $8 \mathrm{~min}$ with a carrier gas at $1.0 \mathrm{~mL} / \mathrm{min}$. Both the temperatures of the MS transfer line and the injector were set at $250^{\circ} \mathrm{C}$. One microliter of essential oil sample was injected (in split mode 20:1). The mass spectra were obtained at $70 \mathrm{eV}$ with a mass scan range of 41-400 amu. Compounds of essential oils were identified by matching their mass spectra with data bank mass spectra in NIST5.0 (National Institute of Standards and Technology), and comparing their retention to a homologous series of $n$-alkanes $\mathrm{C}_{8}-\mathrm{C}_{30}$ (Sigma-Aldrich, Steinheim, Germany) under the same operating conditions.

\subsection{Anti- $\mathrm{H}_{3} \mathrm{~N}_{2}$ Virucidal Activity}

\subsubsection{Viruses, Cells, and Cell Culture}

Influenza viruses $\mathrm{H}_{3} \mathrm{~N}_{2}$ (A3/Beijing/30/95) was kindly provided by the Shanghai Municipal Center for Disease Control and Prevention (Shanghai, China).

The host cells of MDCK cells were provided by the Institute of Medicinal Biotechnology, Chinese Academy of Medical Sciences (Beijing, China). The cells were cultured in EMEM (Eagle's minimum essential medium) containing 10\% fetal bovine serum (FBS, Gibco, Life Technologies, Carlsbad, CA, USA), penicillin $\mathrm{G}(100 \mathrm{U} / \mathrm{mL})$, and streptomycin $(100 \mu \mathrm{g} / \mathrm{mL})$. The cells were maintained in a tissue culture flask at $37^{\circ} \mathrm{C}$ and in $5 \%$ humidified atmosphere of $\mathrm{CO}_{2}$.

\subsubsection{Cellular Toxicity Test}

MDCK cells with a density of $1 \times 10^{4}$ cells per well were seeded into 96-well culture plates and incubated for $24 \mathrm{~h}$ until the cells reached $90 \%$ confluency. After incubation, the cells were treated with various concentrations of essential oil $\left(200,100,50,25\right.$, and $\left.12.5 \mu \mathrm{g} \cdot \mathrm{mL}^{-1}\right)$ dilutions with RPMI-1640 medium containing $10 \% \mathrm{FBS}$, penicillin $\mathrm{G}\left(100 \mu \mathrm{g} \cdot \mathrm{mL}^{-1}\right)$, and streptomycin $\left(100 \mu \mathrm{g} \cdot \mathrm{mL}^{-1}\right)$, respectively. These dilutions were incubated at $37{ }^{\circ} \mathrm{C}$ in $5 \% \mathrm{CO}_{2}$ for $72 \mathrm{~h}$. The cytotoxicity of the essential oil was determined by modified MTT assay, and cell viability was expressed with optical density.

\subsubsection{Determination of Anti- $\mathrm{H}_{3} \mathrm{~N}_{2}$ Activity}

The antiviral activity was assessed by CPE (inhibition of viral cytopathic effect) assay [7]. MDCK cells were seeded into 96-well culture plates and incubated for $24 \mathrm{~h}$ at $37^{\circ} \mathrm{C}$ in humidified $5 \% \mathrm{CO}_{2}$. Afterwards, cells were infected with influenza $\mathrm{A} \mathrm{H}_{3} \mathrm{~N}_{2}$ virus of $30 \mathrm{TCID}_{50}$ and incubated for $2 \mathrm{~h}$ 
at $37{ }^{\circ} \mathrm{C}$ and in a humidified $5 \% \mathrm{CO}_{2}$ atmosphere. Then, the supernatant was carefully removed. Subsequently, the cultures were treated with $100 \mu \mathrm{L} \mathrm{W}$. glabra essential oil at different concentrations $\left(200,100,50,25\right.$, and $\left.12.5 \mu \mathrm{g} \cdot \mathrm{mL}^{-1}\right)$ and with a positive control drug (ribavirin), respectively, and incubated for $72 \mathrm{~h}$ at $37{ }^{\circ} \mathrm{C}$ in a humidified $5 \% \mathrm{CO}_{2}$ atmosphere. The CPE was observed to evaluate the antiviral activity of W. glabra essential oil, and $\mathrm{IC}_{50}(50 \%$ inhibitory concentration) was calculated.

\subsection{Anti-Inflammatory}

NO production was assessed according to the Griess reaction. Dexamethasone (DEX) was selected as a positive control. RAW 264.7 cells were provided by the Department of Pharmacology, School of Pharmacy, Fudan University, Shanghai, China. Each tested sample was dissolved in DMSO, and diluted with fresh FBS-free DMEM media to a final concentration with DMSO $\leq 0.02 \%$. The RAW 264.7 macrophages were seeded in 96-well plates $\left(2 \times 10^{5}\right.$ cells $\left./ \mathrm{mL}\right)$ and co-incubated with samples (concentrations of 4,20 , and $100 \mu \mathrm{g} \cdot \mathrm{mL}^{-1}$ ) and LPS $\left(10 \mathrm{ng} \cdot \mathrm{mL}^{-1}\right)$. After incubation at $37^{\circ} \mathrm{C}$ for $24 \mathrm{~h}$, the culture supernatant was mixed with $25 \mathrm{~mL}$ Griess reagent with $(0.2 \% \mathrm{~N}-(1$-naphtyl) ethylenediamine dihydrochloride and $25 \mu \mathrm{L}$ of $2 \%$ sulphanilamide in $5 \%$ phosphoric acid solution) to determine NO production. Absorbance was measured at $570 \mathrm{~nm}$ using a microtiter plate reader.

\subsection{Anti-Complementary Activity}

Anti-complementary activation was assessed by the classical pathway based on the degree of hemolysis of erythrocytes. The various concentrations of essential oil of W. glabra were, respectively, dissolved in DMSO (dimethyl sulfoxide) and then diluted with barbital-buffered saline (BBS) (containing $0.1 \%$ gelatin, $0.5 \mathrm{mM} \mathrm{Mg}^{2+}, 0.15 \mathrm{mM} \mathrm{Ca}^{2+}$, and $\mathrm{pH} 7.0$ ). The DMSO final concentration was kept less than $1 \%$ to avoid interference with the complementary activities detection. Sensitized erythrocytes (EA) were prepared by incubating sheep erythrocytes $\left(4.0 \times 10^{8}\right.$ cells $\left./ \mathrm{mL}\right)$ with rabbit anti-sheep erythrocyte antibody. Various dilutions of tested samples $(200 \mu \mathrm{L})$ were mixed with $200 \mu \mathrm{L}$ of diluted guinea pig serum (1:80) and $200 \mu \mathrm{L}$ EA. The mixture was incubated at $37^{\circ} \mathrm{C}$ for $30 \mathrm{~min}$ and centrifuged for $5 \mathrm{~min}$. The optical density of the supernatant $(200 \mu \mathrm{L})$ was measured at $405 \mathrm{~nm}$ with a spectrophotometer.

\section{Conclusions}

In conclusion, the present study is the first to report the essential oil composition and bioactivities of W. glabra from Tibet, China. The essential oil of W. glabra showed anti-influenza and anti-inflammatory effects, but no anti-complementary activity. The essential oil and the non-volatile extract should play different roles on the medical use of W. glabra. However, the composition of the essential oil W. glabra from Gangs Rinpoche Mountain (Trans-Himalaya Mountain Range in Tibet) were quite different from the reported W. glabra sample from Nepal. Thus, further comparison of the bioactivities and active compounds of W. glabra samples from north, south, and trans-Himalaya regions will be of great importance.

Acknowledgments: This work was supported by grants from the Tibetan autonomous region science and technology projects, China (Z2012Z01G03), Talents development program of Mount Qomolangma Scholar, Tibet University, China, and the National Natural Science Foundation of China (81673690). We thank Wei-dong Zhu and Lhaqiong for identifying the Waldheimia glabra samples and Dao-Feng Chen for providing the experimental platform.

Author Contributions: J.D., Y.L. and Y.Z. conceived and designed the experiments; J.D., Y.L., L.J. and N.P. performed the experiments and analyzed the data; J.D. and Y.L. wrote the paper.

Conflicts of Interest: The authors declare no conflict of interest.

\section{References}

1. Editorial Committee of Chinese Flora. Flora of China; Science Press: Beijing, China, 1999; Volume 76, p. 84. 
2. Grytnes, J.A.; Vetaas, O.R. Species richness and altitude: A comparison between null models and interpolated plant species richness along the Himalayan altitudinal gradient, Nepal. Am. Nat. 2002, 159, $294-304$. [CrossRef] [PubMed]

3. Giorgi, A.; Panseri, S.; Mattara, M.S.; Andreis, C.; Chiesa, L.M. Secondary metabolites and antioxidant capacities of Waldheimia glabra (Decne.) Regel from Nepal. J. Sci. Food Agric. 2013, 93, 1026-1034. [CrossRef] [PubMed]

4. Manzo, A.; Musso, L.; Panseri, S.; Iriti, M.; Dallavalle, S.; Catalano, E.; Scarì, G.; Giorgi, A. Screening of the chemical composition and bioactivity of Waldheimia glabra (Decne.) Regel essential oil. J. Sci. Food Agric. 2016, 96, 3195-3201. [CrossRef] [PubMed]

5. Bakkali, F.; Averbeck, S.; Averbeck, D.; Idaomar, M. Biological effects of essential oils-A review. Food Chem. Toxicol. 2008, 46, 446-475. [CrossRef] [PubMed]

6. Chinese Pharmacopoeia Commission. Pharmacopoeia of the People's Republic of China; China Medical Science Press: Beijing, China, 2015; Volume 4, p. 2204.

7. Armstrong, J.A. Cytopathic effect inhibition assay for interferon: Microculture plate assay. Methods Enzymol. 1981, 78, 381-387. [PubMed]

8. Lee, C. J.; Chen, L. G.; Liang, W. L.; Wang, C.C. Anti-inflammatory effects of Punica granatum Linne in vitro and in vivo. Food Chem. 2010, 118, 315-322. [CrossRef]

9. Yin, X.; Lu, Y.; Cheng, Z.H.; Chen, D.F. Anti-Complementary Components of Helicteres angustifolia. Molecules 2016, 21, 1506. [CrossRef] [PubMed]

10. Murugan, R.; Mallavarapu, G.R. $\alpha$-Bisabolol, the main constituent of the essential oil of Pogostemon speciosus. Ind. Crops Prod. 2013, 49, 237-239. [CrossRef]

11. Silvério, M.S.; Del-Vechio-Vieira, G.; Pinto, M.A.; Alves, M.S.; Sousa, O.V. Chemical composition and biological activities of essential oils of Eremanthus erythropappus (DC) McLeisch (Asteraceae). Molecules 2013, 18, 9785-9796. [CrossRef] [PubMed]

12. Rocha, N.F.M.; Rios, E.R.V.; Carvalho, A.M.R.; Cerqueira, G.S.; de Araújo Lopes, A.; Leal, L.K.A.M.; Dias, M.L.; de Sousa, D.P.; de Sousa, F.C.F. Anti-nociceptive and anti-inflammatory activities of (-)- $\alpha$-bisabolol in rodents. Naunyn-Schmiedeberg's Arch. Pharmacol. 2011, 384, 525-533. [CrossRef] [PubMed]

13. Shi, Y.; Dong, J.W.; Zhao, J.H.; Tang, L.N.; Zhang, J.J. Herbal insomnia medications that target GABAergic systems: A review of the psychopharmacological evidence. Curr. Neuropharmacol. 2014, 12, $289-302$. [CrossRef] [PubMed]

14. Glaser, J.; Schultheis, M.; Moll, H.; Hazra, B.; Holzgrabe, U. Antileishmanial and cytotoxic compounds from Valeriana wallichii and identification of a novel nepetolactone derivative. Molecules 2015, 20, 5740-5753. [CrossRef] [PubMed]

15. Medeiros, L.B.P.; Rocha, M.D.S.; Lima, S.G.D.; Júnior, G.R.D.S.; Citó, A.M.D.G.L.; Silva, D.D.; Lopes, J.A.D.; Moura, D.J.; Saffi, J.; Mobin, M.; et al. Chemical constituents and evaluation of cytotoxic and antifungal activity of Lantana camara essential oils. Rev. Bras. Farmacogn. 2012, 22, 1259-1267. [CrossRef]

16. Hammami, S.; Jmii, H.; Mokni, R.E.; Khmiri, A.; Faidi, K.; Dhaouadi, H.; Aouni, M.H.E.; Aouni, M.; Joshi, R.K. Essential Oil Composition, Antioxidant, Cytotoxic and Antiviral Activities of Teucrium pseudochamaepitys Growing Spontaneously in Tunisia. Molecules 2015, 20, 20426-20433. [CrossRef] [PubMed]

17. Callan, N.W.; Johnson, D.L.; Westcott, M.P.; Welty, L.E. Herb and oil composition of dill (Anethum graveolens L.): Effects of crop maturity and plant density. Ind. Crops Prod. 2007, 253, 282-287. [CrossRef]

18. Melito, S.; Petretto, G.L.; Podani, J.; Foddai, M.; Maldini, M.; Chessa, M.; Pintore, G. Altitude and climate influence Helichrysum italicum subsp. microphyllum essential oils composition. Ind. Crops Prod. 2016, 80, 242-250. [CrossRef]

19. Cun, Y.Z.; Wang, X.Q. Plant recolonization in the Himalaya from the southeastern Qinghai-Tibetan Plateau: Geographical isolation contributed to high population differentiation. Mol. Phylogenet. Evol. 2010, 56, 972-982. [CrossRef] [PubMed]

Sample Availability: Not Available.

(C) 2017 by the authors. Licensee MDPI, Basel, Switzerland. This article is an open access article distributed under the terms and conditions of the Creative Commons Attribution (CC BY) license (http:/ / creativecommons.org/licenses/by/4.0/). 